\title{
Extensive Osseous Metaplasia With Mature Bone Formation of Thyroid Gland
}

\author{
Murat Basbug ${ }^{\mathrm{a}, \mathrm{c}}$, Rldvan Yavuz ${ }^{\mathrm{a}}$, Mahmut Dablan ${ }^{\mathrm{a}}$, Bulent Akansu ${ }^{\mathrm{b}}$
}

\begin{abstract}
Multinodular goiter is a disease frequently encountered in endocrine surgery. Although histopathological examination of the thyroid gland often reveals fibrosis, calcification, degenerative and cystic changes, and hemorrhagic tissue, osseous metaplasia is a very rare phenomenon in the thyroid gland. We present a case of multinodular goiter with histological osseous metaplasia and mature bone formation in a 65 years old female patient.
\end{abstract}

Keywords: Osseous metaplasia; Mature bone formation; Thyroid

\section{Introduction}

Goiter is a common endocrine disorder throughout the world. In Turkey, thyroid disease is estimated to affect approximately $7 \%$ of the population, with $50 \%$ of cases involving a thyroid nodule. The incidence of thyroid nodules

Manuscript accepted for publication April 6, 2012

${ }^{a}$ Department of Surgery, Diyarbakir Education and Research Hospital, 21400, Diyarbakir, Turkey

${ }^{\mathrm{b}}$ Department of Pathology, Diyarbakir Education and Research

Hospital, 21400, Diyarbakir, Turkey

${ }^{\mathrm{c} C}$ Corresponding author: Murat Basbug.

Email: basbugmurat76@gmail.com

doi:10.4021/jem $98 \mathrm{w}$ increases with age and women are four times more likely to be affected than men. Histopathological evaluation of the thyroid reveals fibrosis, calcification, degenerative and cystic changes, and hemorrhagic tissue [1]. Osseous metaplasia $(\mathrm{OM})$ or ectopic bone formation (EBF) are very rare entities $[2,3]$. OM or EBF is defined by the presence of heterotrophic normal bony tissue within a soft tissue. Extensive bone formation has been observed in malignant thyroid tumors but is rarely reported in benign thyroid diseases [4]. Here, we present a case of multinodular goiter with histological osseous metaplasia and mature bone formation.

\section{Case Report}

A 65-year-old female was admitted to our surgery clinic with a history of intermittent neck pain and swelling. She had noticed a lump in the front of the neck two years previously. The patient's medical background revealed no previous irradiation or serious disease. Physical neck examination revealed a grade III multinodular goiter. On palpation, the thyroid gland was found to be semi-solid tissue with a solid nodule approximately $4 \mathrm{~cm}$ in diameter in the left lobe. No

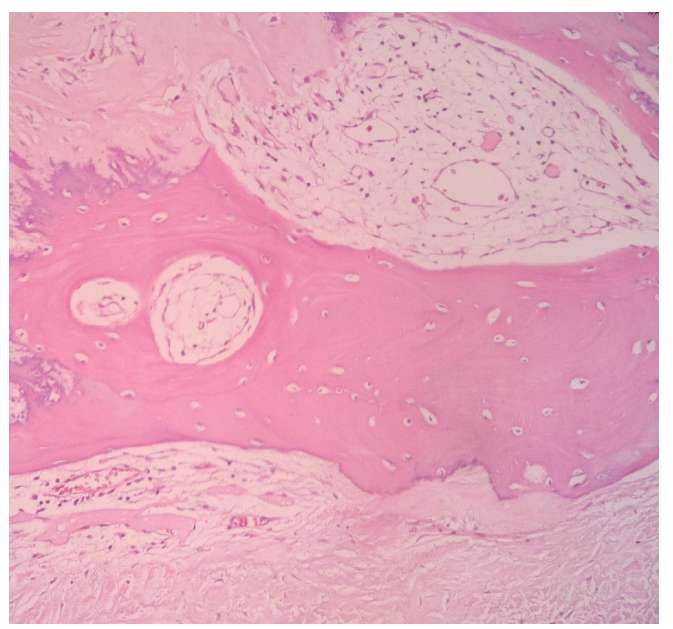

Figure 1. Osseos metaplasia and bone formation in thyroid tissue $(H$ and $E, x 100)$ 
lymphadenopathy was evident in the cervical region. Laboratory test results, including complete blood counts, coagulation profiles and thyroid hormone levels were also within normal limits. Biochemical parameters of calcium were 10.2 $\mathrm{mg} / \mathrm{dL}$ (8.4 - $10.2 \mathrm{mg} / \mathrm{dL})$, phosphorus $3.43 \mathrm{mg} / \mathrm{dL}$ (2.3 - 4.7 $\mathrm{mg} / \mathrm{dL})$, and parathormone $37 \mathrm{pg} / \mathrm{mL}(14$ - $72 \mathrm{pg} / \mathrm{mL})$. Preoperative liver and renal function tests were normal. Cervical radiography showed no calcification. Ultrasound of the thyroid showed multiple nodular lesions, the largest measuring $30 \times 44 \mathrm{~mm}$ and having increased vascularity and intense calcification in the left lobe of the thyroid gland. USG findings were suggestive of malignancy. The lymph node was not observed in the USG examination. Fine needle aspiration biopsy (FNAC) of thyroid nodul yielded insufficient material for analysis. Total thyroidectomy was performed, and histopathology of hematoxylin and eosin stained paraffin sections showed nodular hyperplastic, densely calcified thyroid tissue consistent with multinodular goiter. A section from bilateral lobes demonstrated intense calcification, common hyalinization, and mature metaplastic bone with lamellae (Fig. 1).

\section{Discussion}

Thyroid disease is a common endocrine disorder throughout the world. Thyroid diseases are benign or malignant disorders that affect the structure and function of the thyroid gland [5]. Thyroid histopathology typically shows hemorrhage, fibrosis, calcification, and cystic changes [6].

Dystrophic calcification and mature bone formation are usually observed in necrotic areas of the malign neoplasm. $\mathrm{OM}$ in the thyroid has been described in association with neoplasms such as teratomas and sarcomas [7-9]. But severe osseous metaplasia with bone formation is a very rare phenomenon in benign thyroid diseases such as multinodular goiter. OM is usually observed in thyroid samples as incidental microscopic findings. Isole osseous metaplasia with ectopic bone formation in the thyroid gland was first described in the English literature by Tzanakakis et al. in 1979 [10]. The case presented here describes the second known example of this phenomenon in the English literature.

The etiopathogenesis of osseous metaplasia is still unclear. Various theories have been proposed. Bone morphogenic proteins (BMP) play an important role in bone formation by inducing local ossification and synthesizing ground substance and collagen, but the final step in bone formation depends on adequate concentrations of calcium and phosphate [11]. A study published on 12th January 2012, conducted by the Tumor Research Center, showed that calcified thyroid tissue has significantly higher expression of BMP-2 than normal thyroid tissue.

In conclusion, we have reported a very rare case of multinodular goiter with extensive osseous metaplasia. Although the ethiopathogenesis of this phenomenon remains unclear, it is likley that BMP-2 is important to the aberrent calcification pathway.

\section{Author Contributions}

Basbug $\mathrm{M}$ and Yavuz R performed the surgical procedure, Akansu B performed histopathologic examination. Basbug $M$ contributed writing the article and review of the literature, as well as undertaking a comprehensive literature search; Basbug M, Dablan M and contributed design and manuscript preparation.

\section{Conflict of Interest}

The author(s) declare that they have no competing interests.

\section{References}

1. LiVolsi VA 2000 Pathology of thyroid diseases. In: Braverman LE, Untiger RE (eds) Werner \& Ingbar's The Thyroid: A Fundamental and Clinical Text. Lippincott Williams \&Wilkins, Philadelphia, pp. 488-511.

2. Ardito G, Fadda G, Revelli L, Modugno P, Lucci C, Ardito F, Pontecorvi A, et al. Follicular adenoma of the thyroid gland with extensive bone metaplasia. J Exp Clin Cancer Res. 2001;20(3):443-445.

3. Harsh M, Dimri P, Nagarkar NM. Osseous metaplasia and mature bone formation with extramedullary hematopoiesis in follicular adenoma of thyroid gland. Indian J Pathol Microbiol. 2009;52(3):377-378.

4. S. Agnihotri, N.H. Sarma, N. Jeebun, R. Srivastava: Osseous Metaplasia In Of The Rectum: A Case Report. The Internet Journal of Gastroenterology. 2008 Volume 7 Number 1

5. Ogbera AO, Kuku SF. Epidemiology of thyroid diseases in Africa. Indian J Endocrinol Metab. 2011;15(Suppl 2):S82-88.

6. Westhoff CC, Karakas E, Dietz C, Barth PJ. Intrathyroidal hematopoiesis: a rare histological finding in an otherwise healthy patient and review of the literature. Langenbecks Arch Surg. 2008;393(5):745-749.

7. Byard RW, Thomas MJ. Osseous metaplasia within tumours. A review of 11 cases. Ann Pathol. 1988;8(1):6466.

8. Pontikides N, Botsios D, Kariki E, Vassiliadis K, Krassas GE. Extramedullary hemopoiesis in a thyroid nodule with extensive bone metaplasia and mature bone formation. Thyroid. 2003;13(9):877-880.

9. Bataille S, Daniel L, Legris T, Vacher-Coponat H, Purgus R, Berland Y, Moal V. Osseous metaplasia in a kidney allograft. Nephrol Dial Transplant. 2010;25(11):3796- 
3798.

10. Tzanakakis GN, Scopa CD, Vezeridis MP, Vagenakis A. Ectopic bone in multinodular goiter. R I Med J. 1989;72(5):171-172.
11. Akbulut S, Yavuz R, Akansu B, Sogutcu N, Arikanoglu Z, Basbug M. Ectopic bone formation and extramedullary hematopoiesis in the thyroid gland: report of a case and literature review. Int Surg. 2011;96(3):260-265. 